\title{
EGG LENGTH OF ANASTREPHA OBLIQUA MACQUART (DIPTERA, TEPHRITIDAE) ACCORDING TO OVIPOSITION RATE AND MATERNAL AGE
}

\author{
Isabel C. Boleli ${ }^{1}$ \\ M. Madalena da Costa Teles ${ }^{1}$
}

\begin{abstract}
The length of the entire egg, micropile and vitellus regions of Anastrepha obliqua Macquart, 1835 were measured during all oviposition period. Obtained values were compared among them and with oviposition rate. The smallest eggs were produced during the first 35 oviposition days, period where the highest oviposition rate occured. The decrease in egg length was found to be due to a descrease in the vitellus region. Micropile length was found to be pratically constant throughout oviposition. Furthermore, no relationship between maternal age and length was detectable.

KEY WORDS. Anastrepha obliqua, fruit fly, egg length, oviposition rate
\end{abstract}

Changes in egg size are one of the possible maternal adaptive responses to genetic differences or selective pressure imposed by the environment. Some selective factors that may elucit this type of response are female age (LABINE, 1968; RICHARDS \& MAYERS, 1980; JONES et al., 1982; KARLSSON \& WIKLUND, 1984; BUTLIN et al., 1987), nutritional reserves (KARLSSON, 1987), quantity and quality of adult diet (MURPHY et al., 1983; MOORE \& SINGER, 1987; TESTERINK, 1982), exposure to competitors and predators (SLANSKY \& RODRIGUEZ, 1987), and oviposition rate (KASULE, 1990).

According to LABEYRIE $(1967,1988)$, many of the maternal effects on progeny are mediated via the egg. This can significantly affect the phenotype of later stages since development is a process in which the performance of each stage of the life cycle generally depends on the sucess of the previous stage (SLANSKY \& RODRIGUEZ, op. cit.) and the adult phenotype is the sum of the activities performed throughout the life of the individual (MOUSSEAU \& DINGLE, 1991).

In view of the importance of the above considerations in terms of the physiology of development, the understanding of insect's function within the ecosystem and the development of an effective management program, the present study was undertaken to determine whether oviposition rate and maternal age have any effect on egg length in $A$. obliqua Macquart, 1835.

1) Departamento de Biologia, Universidade de São Paulo, Av. Bandeirantes, 3900, 14031-450 Ribeirão Preto, São Paulo, Brasil. 


\section{MATERIAL AND METHODS}

Adults were reared from host fruits (Spondias purpurea) ("ceriguela") collected from February to April 1989 at the COPERSUCAR orchard, Sertãozinho, São Paulo. The infested fruits were maintained on a layer of sand in plastic trays, according to BRESSAN (1981). Since this fruit is normally infested by different tephritid species, the morphological characters of the collected adults and of their eggs were analyzed based on ZUCCHI (1979) and SIMÕES-JORGE (1987), respectively, to certify that only $A$. obliqua flies would be used.

Ten cages each containing 40 females and 20 males which had emerged during a period of 12 hours were set up. Maintenance of adults flies was realized as described in POLLONI (1981) e SILVA et al. (1985), as follows. Cages consisted of iron frames $(21 \times 21 \times 21 \mathrm{~cm})$ covered with white nylon netting. The adults food cointained a mixture of brewer's yeast, sucrose, starch, agar, propionic acid and distilled water. Water was kept available at all times. The cages were maintained at $27^{\circ} \mathrm{C}$ and $75 \%$ relative humidity.

Oviposition substrates in the form of semi-spheres were done dipping the yellow and green mussylon spheres into the a 7:1 mixture of meldet paraffin and nett vaseline, according to the methods of SIMÕES-JORGE (1987). Eggs were collected daily during all oviposition period. Approximately 10-15 eggs from each cage were separated and measured under a magnifying glass with the aid of a Wild (10x) ocular micrometer, for a total of 3100 eggs. In addition to total length, micropile (M) and vitellus (V) lengths were measured, which are both clearly distinguishable under a magnifying glass. The morphometric data obtained for these two regions and total egg length were grouped into 5-days intervals since oviposition time was quite long. Data were analyzed statistically by the Kruskal-Wallis test (SIEGEL, 1975) and by the multiple comparisons Kruskal-Wallis test (HOLLANDER \& WOLFE, 1973).

During the oviposition period, the number of eggs detected in the oviposition receptacles and the number of live females present in each cage were recorded daily for the calculation of oviposition rate per female.

\section{RESULTS}

Figure 1A shows that $A$. obliqua females presented a longlasting oviposition activity (approximately from the $5^{\text {th }}$ to the $120^{\text {th }}$ day). This activity was marked by a greater oviposition rate during the first 35 days, which was followed by a marked reduction in egg production. Another increase in oviposition rate had begun on the $80^{\text {th }}$ day but did not reach the values observed at the beginning of the activity.

Mean length ranged from $0.12 \pm 0.01$ to $0.16 \pm 0.02 \mathrm{~mm}$ for region " $\mathrm{M}$ " and from $0.88 \pm 0.02$ to $0.97 \pm 0.03 \mathrm{~mm}$ for region "V". Mean total egg length ranged from $1.04 \pm 0.04$ to $1.12 \pm 0.03 \mathrm{~mm}$ (Figs 1B, 1C, 1D).

Statistical analysis of the data referring to the lengths of regions " $\mathrm{M}$ " and 

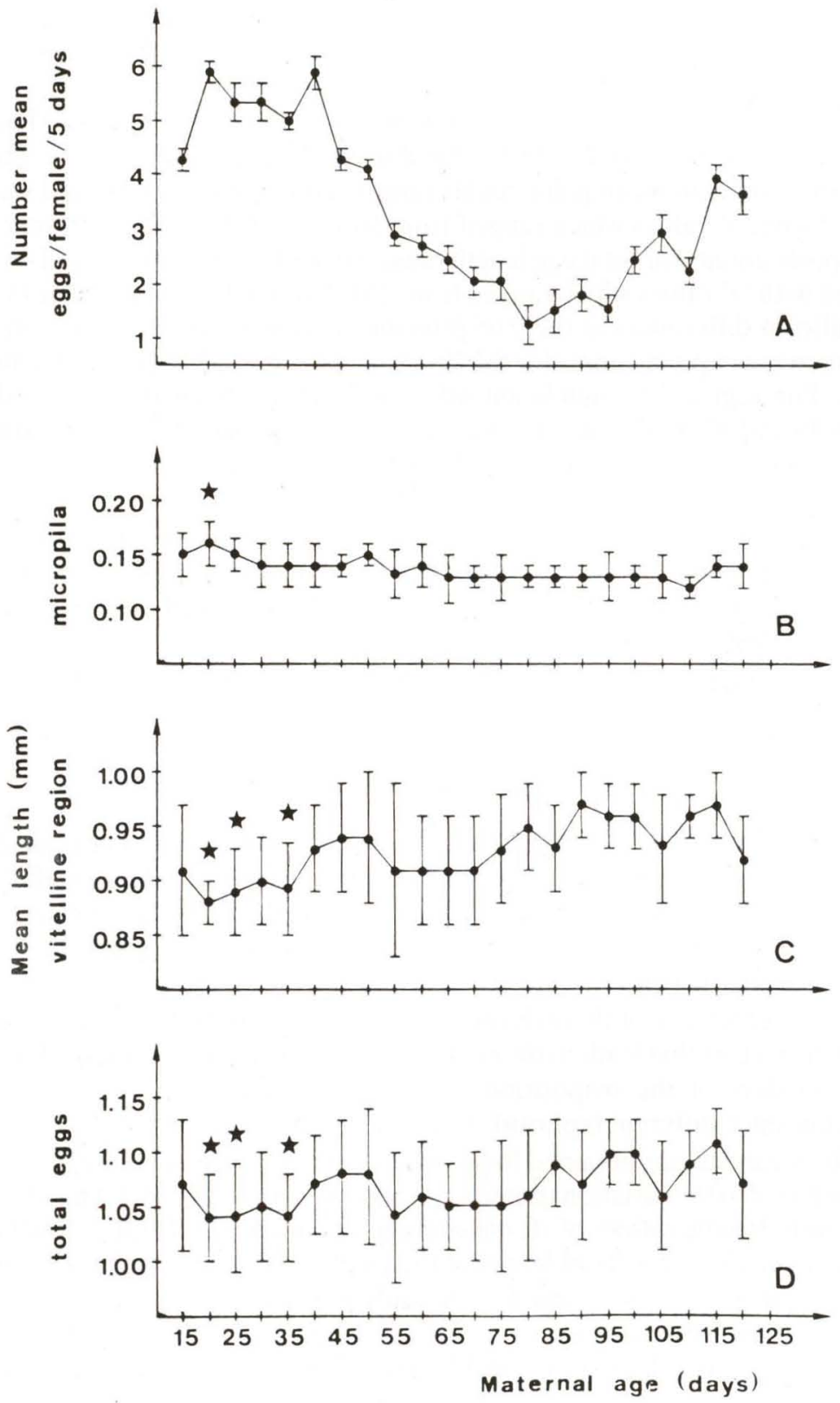

Fig. 1. Variation in oviposition rate (A) and mean total lengths of micropile (B), vitellus region (C) and of eggs (D) of $\mathbf{A}$. obliqua according to female age. The asterisks indicate the means that are statistically different from the others $(p<0.05)$. 
"V" by the Kruskal-Wallis test revealed that both presented significant differences throughout the oviposition period $(\mathrm{H}=497.07 ; \mathrm{H}=536.69$; $\mathrm{p}<0.001$; d.f. $=21$, respectively). The same occurred for total egg length $(\mathrm{H}=303.17$; $<<0.001$; d.f. $=21)$. In the multiple comparisons test among the 22 age intervals, mean point counts for region " $\mathrm{M}$ " ranged from 3.65 to 1645.41 and were compared with " $\mathrm{z}$ " values which ranged from 237.47 to 1328.55 . For region "V", the differences in mean point counts ranged from 0.98 to 1645.40 and were compared with " $\mathrm{z}$ " values which ranged from 56.75 to 1275.52 . The differences in mean point counts for total egg length ranged from 11.19 to 1400.57 and were compared with " $z$ " values which ranged from 250.91 to 1301.06 . The test showed that significant differences at the 0.05 probality level were detected for region "M" between mean point counts for the 20-25 day age internal and the remaining intervals. For region "V", significant differences were obtained between the 20-25, 25-30 and 35-40 day age intervals and the remaining intervals. For total egg length, significant differences were detected between mean point counts for the same age intervals as for region "V".

The age intervals for which significant differences were obtained for total and "V" lengths correspond to the intervals for which the lowest values were obtained $(0.88 \pm 0.02 \mathrm{~mm}$ and $0.89 \pm 0.04 \mathrm{~mm} ; 1.04 \pm 0.04 \mathrm{~mm}$ and $1.04 \pm 0.05 \mathrm{~mm}$, respectively) (Figs $1 \mathrm{C}, 1 \mathrm{D}$ ).

Smaller eggs were produced at the beginning of the oviposition period, i.e., females were still young.

\section{DISCUSSION}

For a parasite to be successful, synchronism must occur between the appropriate stages of its life cycle and periods of greatest host avaibility (SLANSKY \& RODRIGUEZ, 1987). Thus, the embryonic and larval stages of A. obliqua must be synchronous with fruit growth and ripening, since the fruit flies occur inside the fruit.

The dependence of these developmental phases on the host (fruit) must be one of the factors that leads to the highest oviposition rate of $A$. obliqua during the first 35 days of the oviposition period. Another factor is interspecific competition since different tephritid species infest the same fruit.

The mean lengths obtained for region " $\mathrm{M}$ " during oviposition varied little when compared to the variations detected in region "V" (Figs 1B, 1C). This shows that the wide length variety of $A$. obliqua egg detected by SIMOES-JORGE (1987) is due to the diversity of length of the vitellus region (V) and not to that of the micropile region, as assumed by the author. Furthermore, comparison of the lengths of these two regions with total egg length (Figs 1B, 1C, 1D) shows that the curve obtained for mean total length is similar to that for the vitellus region (V).

The smallest eggs were produced during the intervals in wich region " $\mathrm{V}$ " presented the shortest lengths. Thus, these data demonstrate that smaller eggs present a reduction in the length of the vitellus region (V). 
According to the present data, the smallest eggs were produced during the greatest oviposition activity period, suggesting that an elevated egg production must reduce the amount of nutrients available for each egg or that the rapid egg production must decrease nutrient incorporation. A decrease in egg length related to the amount of nutrient reserves in females has been reported by KARLSSON (1987) for Lepidoptera, and a reduction due to oviposition rate has been reported by KASULE (1991) for Homoptera.

Several investigators have shown that egg size varies with female age (LABINE, 1968; JONES et al., 1982; BOGGS, 1986; KARLSSON \& WIKLUND, 1984). Our study demonstrated that the smallest eggs are produced by young females but only because of the high oviposition rate occurring at that age. The observation that the size of $A$. obliqua eggs is not statistically homogeneous throughout the oviposition period indicates that the use of egg length measurements as a comparative trait among tephritid species should be considered with caution. In our opinion, the present data indicate that the number of eggs used in future studies on fruit flies should be bigger and that the samplings should be performed on different days during the oviposition period.

The present results have raised two new question: is embryonic development faster in smaller eggs? Can the reduced length of the vitellus region impair egg viability? According to studies conducted by CAREY et al. (1985) and FITT (1990) on the tephritids Dacus cucurbitae (Coquillett,1899) and D. cucumis French, respectively, larger eggs present a shorter time of development. However, no information is available about the speed of development of Anastrepha species. As to the second question, according to NEILSON \& MCALLAN $^{*}(1965)$ and POLLONI (1981), the viability of $A$. obliqua eggs does not seem to be impaired since percent hatching in this and other tephritid species is higher during the greatest oviposition activity.

Finally, our data show that $A$. obliqua females produce smaller eggs during the period of highest oviposition rate and that this reduction in size affects the length of the vitellus region.

ACKNOWLEDGMENTS. The authors are grateful to "Coordenadoria de Aperfeiçoamento de Pessoal de Nível Superior" (CAPES) for financial support, and to COPERSUCAR for permitting the use of their orchard for fruit collection.

\section{BIBLIOGRAPHIC REFERENCES}

BOGGS, C.L. 1986. Reproductive strategies of female butterflies: variation and constraints on fecundity. Ecol. Ent. 11: 7-15.

BRESSAN, S. 1981. Aspectos biológicos de algumas espécies do gênero Anastrepha Schiner, 1868 (Diptera - Tephritidae) na região de Ribeirão Preto. Dissertação de Mestrado, não publicada, Universidade de São Paulo, 250p.

BUTLIN, R.K.; C.W. WOODHATCH \& G.W. HEWITT. 1987. Spermatophore investment increases female fecundity in a grasshopper. 
Evolution 41: 221-225.

CAREY, J.R.; E.J. HARRIS \& D.O. MCINNIS. 1985. Demography of a native strain of the Melon fly, Dacus cucurbitae, from Hawaii. Ent. Exp. Appl. 338: 195-199.

FITT, G.P. 1990. Variation in ovariole number and egg size of species of Dacus (Diptera - Tephritidae) and their relation to host specialization. Ecol. Entomol. 15: 255-264.

HOLLANDER, M. \& D.A. WOLF. 1973. Non-Parametric Statistical Methods. New York, John Wiley \& Sons, 503p.

JONES, R.E.; J.R. HART \& G.D. BULL. 1982. Temperature, size and egg production in the cabbage butterfly, Pieris rapae L. Aust. J. Zool.30: 223-232.

KARLSSON, B. 1987. Variation in egg weight, oviposition rate and reproductive reserves with female age in a natural population of the speckled wood butterfly, Pararge aegeria. Ecol. Ent. 12: 473-476.

KARLSSON, B. \& C. WIRLUND. 1984. Egg weight variation and lack of correlation between egg weight and offspring fitness in the wall brown butterfly Lasiommata megera. Oikos 43: 376-385.

KASULE, F.K. 1991. Egg size increase with maternal age in the cotton stainer bugs Dysdercus fasciatus and D. caedinales (Hemiptera, Pyrrhocoridae). Ecol. Ent. 15: 345-349.

LABEYRIE, V. 1967. Physiologie de la mère et ètat de la progeniture chez les insectes. Bull. Biol. 101: 13-71.

- 1988. Effects maternels et biologie des populations d'insectes. Mem. Ent. Soc. Can. 146: 153-169.

LABINE, P.A. 1968. The population biology of the butterfly, Euphydryas editha. VIII. Oviposition and its relation to patterns of butterflies. Evolution 22: 799-805.

MOORE, R.E. \& M.C. SINGER. 1987. Effects of maternal age and adult diet on egg weight in the butterfly Euphydryas aditha. Ecol. Ent. 12: 401-408.

MOSSEAU, T. \& H. DINGLE. 1991. Maternal effects in insects life histories. Ann. Rev. Ent. 36: 511-534.

MURPHY, D.D.; A.E. LAUNER \& P.R. EHRLICH. 1983. The role of adult feeding in egg production and population dynamics of the checkerspot butterfly Euphydryas editha. Oecologia 56: 257-263.

NIELSON, W.T.A. \& J.W. MCALLAN. 1965. Effects of mating on fecundity of the apple maggot Rhagoletis pomonella (Walsh.). Can. Ent. 97 (5): 276-279.

POLLONI, Y.J. 1981. Aspectos do comportamento reprodutivo de algumas espécies de moscas-das-frutas do gênero Anastrepha Schiner, 1868 (Diptera, Tephritidae) em laboratório. Dissertação de Mestrado, não publicada, Universidade de São Paulo, Ribeirão Preto, 108p.

RICHARDS, L.J. \& J.H. MAYERS. 1980. Maternal influence on size and emergence time of the cinnabar moth. Can. J. Zool. 58: 1452-1457.

SIEGEL, S. 1975. Estatística não-paramétrica - para as Ciências do Comportamento. São Paulo, MacGraw-Hill, XX +350p. 
SILVA, M.T. DA; Y.J. POLLONI \& S. BRESSAN. 1985. Mating behavior of some fruit flies of the genus Anastrepha Schiner, 1868 (Diptera - Tephritidae) in the laboratory. Revta bras. Ent. 29 (1): 155-164.

SIMÕES-JORGE, M.H. 1987. Estudo do desenvolvimento pós-embrionário de moscas-das-frutas do gênero Anastrepha Schiner, 1868 (Diptera Tephritidae). Dissertação de Mestrado, não publicada, Universidade de São Paulo, Ribeirão Preto, 180p.

SLANSKY JR., F. \& J.G. RODRIGUEZ. 1987. Nutricional Ecology of Insects, Mites, Spiders and Related Invertebrates. New York, John Wiley, XVII + 1016p.

TESTERINK, G.J. 1982. Strategies in energy consumption and partioning in Collembola. Ecol. Entomol. 7: 341-351.

ZUCCHI, R. 1979. Taxonomia das espécies brasileiras de Anastrepha Schiner, 1868 do complexo fraterculus (Diptera - Tephritidae). Dissertação de Mestrado, não publicada, Universidade de São Paulo, Piracicaba, 63p.

Recebido em 10.IV.1992; aceito em 25.V.1993. 